\title{
Pengaruh Kompensasi terhadap Kinerja Karyawan Non Manajemen melalui Motivasi dan Komitmen Organisasi (Studi Kasus pada PT. Ewindo)
}

\author{
Apriwandi \\ apriwandi@gmail.com \\ Accounting Study Program, Faculty of Economic \\ Universitas Widyatama, Indonesia \\ Bayu Prasetia \\ Universitas Widyatama, Indonesia
}

\begin{abstract}
Intisari
Penelitian ini bertujuan untuk melihat pengaruh baik secara parsial maupun simultan variabel kompensasi serta motivasi dan komitmen organisasi sebagai variabel intervening terhadap variabel dependenya yaitu kinerja. Penelitian ini menggunakan sumber data primer yaitu kuesioner dengan menggunakan teknik purposive sampling. Sampel disebar kepada 40 responden karyawan non manajemen PT.Ewindo. Dari hasil penelitian menunjukkan bahwa secara parsial seluruh variabel memiliki pengaruh yang signifikan terhadap kinerja (Y) dimana variabel motivasi memiliki nilai koefisien jalur tertinggi yaitu 0,575 atau sebesar $33,1 \%$ pengaruhnya terhadap kinerja. Begitu pula secara simultan, variabel kompensasi, motivasi, komitmen organisasi secara bersama sama memiliki pengaruh yang signifikan terhadap kinerja karyawan dimana Fhitung > Ftabel $(50,959>2,493)$ dengan tingkat signifikansi $<0,05$. Serta memberikan pengaruh sebesar 88,2 \% terhadap kinerja karyawan, sedangkan sisanya sebesar 11,8\% merupakan pengaruh dari variabel lain diluar penelitian.
\end{abstract}

Kata Kunci: kompensasi, motivasi, komitmen organisasi, affective commitment, continuance commitment, normative commitmen, kinerja 


\title{
The Effect of Compensation on Non-Management Employee Performance through Organizational Motivation and Commitment (A Case Study of PT. Ewindo)
}

\author{
Apriwandi \\ apriwandi@gmail.com \\ Accounting Study Program, Faculty of Economic \\ Universitas Widyatama, Indonesia \\ Bayu Prasetia \\ Universitas Widyatama, Indonesia
}

\begin{abstract}
This study aims to analyse the influence of both partial and simultaneous variable which is compensation and the intervening varibles motivation and organizational commitment to performance. This research uses primary data from questionnaire by using purposive sampling technique. The questionnaire is distributed to 40 non management respondents of PT.Ewindo. From the results, it shows that partially all the variables have significant influence on the performance $(\mathrm{Y})$ in which the motivation variable has the highest path coefficient of 0.575 or $33.1 \%$ of the effect on performance. Similarly, simultaneous variables of compensation, motivation, organizational commitment have significant influence on employee performance by which Fcount $>$ Ftable $(50,959>2,493)$ with significance level $<0,05$. The model shows an effect of $88.2 \%$ on employee performance, while the rest of $11.8 \%$ are influenced by other variables outside the study.
\end{abstract}

Keywords: compensation, motivation, organizational commitment, affective commitment, continuance commitment, normative commitment, performance. 


\section{PENDAHULUAN}

Seiring dengan era globalisasi dewasa ini, setiap perusahaan semakin dituntut untuk terus meningkatkan kemampuannya dalam bertahan dan mengahadapi persaingan pasar yang semakin ketat serta bagaimana cara agar perusahaan dapat mencapai tujuan yang telah ditetapkan. Upaya untuk meningkatkan kinerja perusahaan sangatlah penting untuk memberi nilai tambah bagi perusahaan. Kinerja perusahaan secara keseluruhan tidak terlepas dari hasil kerja yang dihasilkan oleh seorang karyawan dalam mengerjakan setiap tugas yang menjadi tanggung jawabnya.

Karyawan yang terdapat di dalam perusahaan memiliki karakteristik yang berbeda beda. Namun pada umumnya mereka bekerja di perusahaan karena adanya suatu motif pemenuhan kebutuhan, tak terkecuali untuk karyawan non manajemen. Di dalam perusahaan manufaktur, karyawan non manajemen ini memiliki kuantitas yang banyak dan memiliki andil yang besar dalam berlangsungnya kegiatan usaha perusahaan. Mereka terlibat langsung dengan hal - hal yang sifatnya teknis dan operasional.

Menyadari akan pentingnya karyawan dalam menjalankan roda perusahaan, sudah sepatutnya perusahaan memberikan timbal balik yang adil dan layak pada karyawan. Pemberian kompensasi merupakan hal yang paling pokok yang diberikan perusahaan sebagai alat pemenuhan kebutuhan karyawan. Lebih lanjut Davis dan Werther (1996) dalam Sudarsono (2008) menyebutkan "ada beberapa tujuan dari pemberian kompensasi, salah satunya untuk memotivasi karyawan.” Hal tersebut mengindikasikan bahwa kompensasi yang memadai akan meningkatkan motivasi karyawan dalam melaksanakan tanggung jawab akan pekerjaan yang dibebankan kepadanya, sehingga tercipta suatu produktivitas dalam bekerja dan tujuan perusahaan dapat tercapai. Kompensasi pun akan mempengaruhi komitmen organisasi dalam tujuannya mempengaruhi kinerja karyawan.

Mathis dan Jackson (2004) dalam Marganingsih dan Martani (2010) mendefinisikan "komitmen organisasi sebagai tingkat sampai dimana pegawai yakin dan menerima tujuan organisasi, serta berkeinginan untuk tinggal bersama organisasi tersebut." Hal tersebut menandakan bahwa seseorang dengan komitmen yang tinggi terhadap organisasinya akan menimbulkan sikap loyal kepada organisasi tempatnya bernaung dan berupaya meningkatkan kinerjanya demi tercapainya tujuan organisasi tersebut.

Allen dan Meyer (1991) membagi derajat komponen komitmen organisasi menjadi tiga komponen, yaitu affective commitment, continuance commitment dan normative commitment. Affective commitment berarti seseorang memiliki keterkaitan secara emosional dan penerimaan nilai nilai organisasi atau perusahaan. Sehingga seseorang dengan komitmen afektif yang tinggi memiliki rasa ingin terus bekerja dan mencapai tujuan organisasi (want to). Sementara continuance commitment berkaitan dengan seseorang yang tetap bekerja di dalam perusahaan karena mereka memang membutuhkannya (need to). Hal ini dikarenakan tidak ada pilihan lain apabila mereka meninggalkan perusahaan tersebut. Dan yang terakhir yaitu normative commitment berkaitan dengan sikap yang merasa bahwa seseorang memang memiliki kewajiban untuk mencapai tujuan perusahaan (ought to).

PT.Ewindo yang menjadi objek penelitian dan berlokasi di Jalan Cimuncang nomor 68 Bandung ini, bergerak dalam industri pembuatan kabel. PT.Ewindo mempekerjakan banyak karyawan sehingga bisa dikategorikan sebagai perusahaan dengan padat karya. Sumber daya manusia yang begitu banyak di perusahaan tersebut harus dikelola dan dimanfaatkan sedemikian rupa agar tercipta kondisi yang kondusif di dalam perusahaan dan terjadi timbal balik yang saling menguntungkan antara karyawan dan perusahaan. Sebagai balas jasa yang dilakukan oleh perusahaan, pemberian kompensasi tentunya sangat diharapkan bagi karyawan agar terciptanya kepuasan dalam bekerja dan para karyawan mampu memenuhi 
kebutuhan individu mereka.

Menurut observasi awal yang penulis lakukan pada PT. Ewindo, baik itu berupa peninjauan terhadap data perusahaan dan melakukan beberapa tanya jawab dengan beberapa karyawan perusahaan. Diketahui bahwa feed back dari perusahaan berupa kompensasi, secara umum kurang memadai, terlebih lagi untuk karyawan bagian marketing yang disebut - sebut sebagai ujung tombak perusahaan.

Karyawan bagian marketing seringkali dituntut untuk menyelesaikan pekerjaan di luar jam kerja namun tidak ada insentif berupa uang lembur. Uang lembur diberikan hanya jika ada persetujuan dari atasannya. Bagian marketing bertanggung jawab dalam penjualan produk - produk perusahaan sehingga seringkali dikaitkan dengan omset penjualan perusahaan. Data dari perusahaan menunjukkan, bahwa omset penjualan dari tahun 2010 hingga tahun 2014 cenderung menurun.

Sementara dalam aktivitas produksi, PT.Ewindo memproduksi lebih banyak dari standar yang telah ditetapkan sehingga akan terdapat kelebihan dalam produksi. Kelebihan produksi tersebut dijadikan buffer stock atau persediaan cadangan apabila di waktu yang akan datang terdapat purchase order dengan item yang sama dan seringkali buffer stock masuk kedalam kategori slow moving stock atau barang - barang yang sulit untuk diperjualbelikan. Tidak hanya itu, setelah barang slow moving stock tidak bisa terjual dalam kurun waktu lebih dari enam bulan, maka akan dijadikan barang scrap atau barang sisa. Scrap ini masih bisa diperjualbelikan namun harganya jauh dari harga asli barang tersebut. Untuk menghindari kerugian perusahaan akibat penjualan scrap yang harganya rendah, diperlukan upaya untuk meningkatkan penjualan barang - barang slow moving stock. Peningkatan target penjualan harus diimbangi dengan kompensasi berupa reward dan bentuk lainnya sehingga mereka akan termotivasi untuk mencapai target penjualan tersebut.

Dalam hal lain, motivasi karyawan non manajemen di dalam bekerja dinilai rendah. Mereka cenderung menunjukkan sikap ketidaktertarikan mereka pada pekerjaannya. Hal tersebut bisa dilihat dari kedisiplinan dan budaya kerja yang tidak baik.

Begitu pula komitmen karyawan terhadap perusahaan yang dikatakan rendah. Akumulasi dari ketidakpuasan karyawan terhadap perusahaan menimbulkan sikap yang tidak loyal karyawan kepada perusahaannya. Tercatat banyak pegawai yang mengundurkan diri dari perusahaan tersebut.

Beberapa peneliti dan literatur akuntansi manajemen telah melakukan penelitiannya tentang hal yang berkaitan dengan kompensasi, motivasi, komitmen serta kinerja karyawan. Namun hasil yang diperoleh sangat beragam dengan kesimpulannya masing - masing. Apriwandi (2013) mengungkapkan bahwa "literatur akuntansi manajemen memberikan gambaran yang beragam mengenai dampak pemberian insentif terhadap kinerja dan tidak terdapat bukti pemberian insentif moneter atau non moneter dapat meningkatkan kinerja."

Berdasarkan uraian di atas, masih terdapat gap antara peneliti yang satu dengan yang lainnya. Hal tersebut menjadi hal yang menarik diteliti lebih lanjut oleh penulis. Maka penulis tertarik untuk mengadakan penelitian ini.

\section{TINJAUAN PUSTAKA}

\section{Kompensasi}

Robbins (1996) mengemukakan: "kompensasi yang mengandung pengertian yang sama dengan upah variabel yaitu bagian dari upah seseorang karyawan yang didasarkan pada suatu ukuran kinerja individual atau organisasi. Upah variabel tersebut terdiri dari upah berdasarkan potongan, bonus, berbagai laba dan berbagai hasil."

Mondy et al., (1993) mengemukakan bahwa bentuk dari kompensasi yang diberikan perusahaan kepada karyawan dapat dikelompokkan menjadi dua, yaitu: 


\section{Financial Compensation}

a. Direct Financial Compensation

b. Indirect Financial Compensation

2. Nonfinancial Compensation

Djati dan Khusaini (2003) menyatakan bahwa kompensasi dapat berperan meningkatkan prestasi kerja dan kepuasan karyawan jika kompensasi dirasakan:

1. Layak dengan kemampuan dan produktivitas pekerja.

2. Berkaitan dengan prestasi kerja

3. Menyesuaikan dengan kebutuhan individu

Lebih lanjut Djati dan Khusaini (2003) menyebutkan bahwa ada beberapa penyebab dari kepuasan dan ketidakpuasan karyawan atas kompensasi yang mereka terima, yaitu:

1. Kepuasan individu terhadap kompensasi berkaitan dengan harapan dan kenyataan terhadap sistem kompensasi. Kompensasi yang diterima tidak sesuai dengan yang diharapkan, apabila kompensasi yang diterima terlalu kecil jika dibandingkan dengan harapannya.

2. Kepuasan dan ketidakpuasan karyawan akan kompensasi juga timbul karena karyawan membandingkan dengan karyawan lain di bidang pekerjaan dan organisaasi sejenis. Rasa ketidakpuasan akan semakin muncul manakala atasan mereka bersifat tidak adil dalam memperlakukan bawahan serta memberikan wewenang yang berbeda untuk karyawan dengan level jabatan yang sama.

3. Karyawan sering salah persepsi terhadap sistem kompensasi yang diterapkan perusahaan. Hal ini terjadi karena perusahaan tidak mengkomunikasikan informasi yang akurat mengenai kompensasi dan tidak mengetahui jenis kompensasi yang dibutuhkan oleh karyawan.

4. Kepuasan dan ketidakpuasan akan kompensasi juga tergantung pada variasi dari kompensasi itu sendiri. Kompensasi tersebut mempunyai fungsi yang berbeda sehingga kombinasi variasi kompensasi yang baik akan memenuhi kebutuhan dan kepuasan karyawan.

\section{Motivasi}

Kondalkar (2007) dalam Apriwandi (2013) mengungkapkan bahwa motivasi adalah "nafsu mendalam yang disebabkan oleh kebutuhan, keinginan dan hasrat yang mendorong seorang individual untuk menggunakan kekuatan fisik dan mental untuk mencapai tujuan."

Peneliti menggunakan teori motivasi (Expectancy Theory). Tiga asumsi pokok Vroom dari teorinya adalah sebagai berikut:

1. Setiap individu percaya bahwa bila ia berprilaku dengan cara tertentu, ia akan memperoleh hal tertentu. Ini disebut sebuah harapan hasil (outcome expectancy) sebagai penilaian subjektif seseorang atas kemungkinan bahwa suatu hasil tertentu akan muncul dari tindakan orang tersebut.

2. Setiap hasil mempunyai nilai, atau daya tarik bagi orang tertentu. Ini disebut valensi (valence) sebagai nilai yang orang berikan kepada suatu hasil yang diharapkan.

3. Setiap hasil berkaitan dengan suatu persepsi mengenai seberapa sulit mencapai hasil tersebut. Ini disebut harapan usaha (effort expectancy) sebagai kemungkinan bahwa usaha seseorang akan menghasilkan pencapaian suatu tujuan tertentu.

\section{Komitmen Organisasi}

Mowday dalam Sopiah (2008) mengungkapkan bahwa "Komitmen organisasi merupakan dimensi perilaku penting yang dapat digunakan untuk menilai kecenderungan karyawan untuk bertahan sebagai anggota organisasi. Komitmen organisasi merupakan 
identifikasi dan keterlibatan seseorang yang relatif kuat terhadap organisasi. Komitmen organisasional adalah keinginan angota organisasi untuk tetap mempertahankan keanggotaannya dalam organisasi dan bersedia berusaha keras bagi pencapaian tujuan organisasi."

Dimensi komitmen organisasi menurut Meyer, Allen dan Smith dalam Greenberg dan Baron (2008) yaitu:

1. Komitmen afektif (affective commitment) mengacu pada hubungan emosional anggota terhadap organisasi. Orang-orang ingin terus bekerja untuk organisasi tersebut karena mereka sependapat dengan tujuan dan nilai dalam organisasi tersebut.

2. Komitmen berkelanjutan (continuance commitment) mengacu pada keinginan karyawan untuk tetap tinggal diorganisasi tersebut karena adanya perhitungan atau analisis tentang untung dan rugi dimana nilai ekonomi yang dirasa dari bertahan dalam suatu organisasi dibandingkan dengan meninggalkan organisasi tersebut.

3. Komitmen normatif (normative commitment)

mengacu pada perasaan karyawan dimana mereka diwajibkan untuk tetap berada di organisasinya karena adanya tekanan dari yang lain.

Faktor-faktor yang dapat mempengaruhi komitmen organisasi antara lain (McShane \& Glinow, 2000):

1. Keadilan dan Kepuasan Kerja

Komitmen organisasi tampaknya sulit dicapai ketika karyawan menghadapi beban kerja yang meningkat di perusahaan tetapi profit yang didapatkan oleh perusahaan hanya dinikmati oleh manajer tingkat atas. Oleh karena itu, perusahaan dapat membangun komitmen organisasi dengan berbagi keuntungan yang diperoleh perusahaan kepada karyawan.

2. Keamanan Kerja

Karyawan membutuhkan hubungan kerja yang saling timbal balik dengan perusahaan. Keamanan kerja harus diperhatikan untuk memelihara hubungan dimana karyawan percaya usaha mereka akan dihargai.

3. Pemahaman Organisasi

Affective commitment adalah identifikasi secara perorangan terhadap organisasi, jadi masuk akal jika sikap ini akan menguat ketika karyawan memiliki pemahaman yang kuat tentang perusahaan.

4. Keterlibatan Karyawan

Karyawan merasa menjadi bagian dari organisasi ketika mereka berpartisipasi dalam pengambilan keputusan yang menyangkut masa depan perusahaan.

5. Kepercayaan Karyawan

Kepercayaan penting untuk komitmen organisasi karena menyentuh jantung dari hubungan kerja. Karyawan merasa wajib bekerja untuk perusahaan hanya ketika mereka mempercayai pemimpin mereka.

\section{Kinerja}

Murty dan Hudiwinarsih (2012) menyatakan bahwa "kinerja merupakan hasil kerja baik kualitas maupun kuantitas yang dihasilkan karyawan atau perilaku nyata yang ditampilkan sesuai dengan tanggung jawab yang diberikan kepadanya."

Tujuan pokok dari pengukuran kinerja adalah untuk memotivasi karyawan dalam mencapai sasaran organisasi dan mematuhi standar perilaku yang telah ditetapkan sebelumnya agar menghasilkan tindakan yang diinginkan (Mulyadi \& Setyawan 1999). 
Secara umum tujuan dilakukan pengukuran kinerja adalah untuk (Gordon, 1993):

1. Meningkatkan motivasi karyawan dalam memberikan kontribusi kepada organisasi.

2. Memberikan dasar untuk mengevaluasi kualitas kinerja masing-masing karyawan.

3. Mengidentifikasi kebutuhan pelatihan dan pengembangan karyawan sebagai dasar untuk menyediakan kriteria seleksi dan evaluasi program pelatihan dan pengembangan karyawan.

4. Membantu pengambilan keputusan yang berkaitan dengan karyawan, seperti produksi, transfer dan pemberhentian.

Sementara itu manfaat sistem pengukuran kinerja adalah (Mulyadi \& Setyawan, 1999):

1. Menelusuri kinerja terhadap harapan pelanggannya dan membuat seluruh personil terlibat dalam upaya pemberi kepuasan kepada pelanggan.

2. Memotivasi pegawai untuk melakukan pelayanan sebagai bagian dari mata-rantai pelanggan dan pemasok internal.

3. Mengidentifikasi berbagai pemborosan sekaligus mendorong upaya-upaya pengurangan terhadap pemborosan tersebut.

4. Membuat suatu tujuan strategi yang masanya masih kabur menjadi lebih kongkrit sehingga mempercepat proses pembelajaran perusahaan.

\section{Kerangka Pemikiran}

Setiap perusahaan memiliki tujuannya masing - masing. Tujuan tersebut dapat dicapai dengan pengelolaan sumber daya yang ada dalam perusahaan khususnya karyawan non manajemen. Namun sejalan dengan hal tersebut karyawan non manajemen pun memiliki kebutuhan yang harus mereka penuhi. Maslow dalam Edy (2002) mengungkapkan bahwa "seorang individu memiliki kebutuhan berdasarkan jenjang yaitu kebutuhan fisiologis, rasa aman, kasih sayang, penghargaan dan aktualisasi diri." Dalam teorinya, penulis tersebut berpendapat bahwa setiap individu pasti mementingkan kebutuhan tingkat dasar terlebih dahulu sebelum memenuhi kebutuhan lainnya yaitu kebutuhan fisiologis seperti sandang, pangan, papan dll.

Untuk menyelaraskan kedua tujuan tersebut maka diperlukan timbal balik yang diberikan perusahaan kepada karyawan atas jasa yang telah diberikan karyawan kepada perusahaan dalam melaksanakan setiap tugas dan tanggung jawabnya. Pemberian kompensasi merupakan hal yang paling pokok yang diberikan perusahaan dan tentunya sangat diharapkan oleh karyawan untuk dijadikan alat pemenuhan kebutuhan. Davis dan Werther dalam Sudarsono (2008) menyebutkan "beberapa tujuan dari pemberian kompensasi salah satunya untuk memotivasi karyawan." Hal tersebut mengindikasikan bahwa kompensasi yang memadai akan meningkatkan motivasi karyawan dalam menjalankan setiap tugas yang menjadi tanggung jawabnya. Sementara Murty dan Hudiwinarsih (2012) menyatakan bahwa "seorang karyawan yang termotivasi akan bersifat energik dan bersemangat dalam mengerjakan tugas - tugas yang diberikan kepadanya." Hal tersebut menandakan bahwa secara tidak langsung motivasi akan meningkatkan kinerja karyawan.

McShane dan Glinow (2000) menyebutkan bahwa "pemberian kompensasi merupakan indikator kepuasan kerja yang paling pokok." Kepuasan kerja nantinya akan mempengaruhi perilaku individu di dalam perusahaan seperti komitmen karyawan terhadap organisasinya. Komitmen organisasi dirasa penting karena menyangkut pencapaian tujuan perusahaan. Mathis dan Jackson (2001) mengungkapkan definisi komitmen organisasi yaitu "tingkat sampai sejauh mana karyawan merasa yakin dan menerima tujuan organisasi, serta berkeinginan untuk tinggal bersama organisasi." Seseorang dengan komitmen organisasi yang tinggi akan berusaha semaksimal mungkin dan mengerahkan kemampuan dalam dirinya demi tercapainya tujuan dari perusahaan. Maka dari itu secara tidak langsung kompensasi 
mempengaruhi kinerja karyawan melalui komitmen organisasi terlebih dahulu.

Berikut adalah gambar paradigma/model penelitian tentang hubungan antara kompensasi, motivasi, komitmen organisasi dan kinerja karyawan non manajemen:

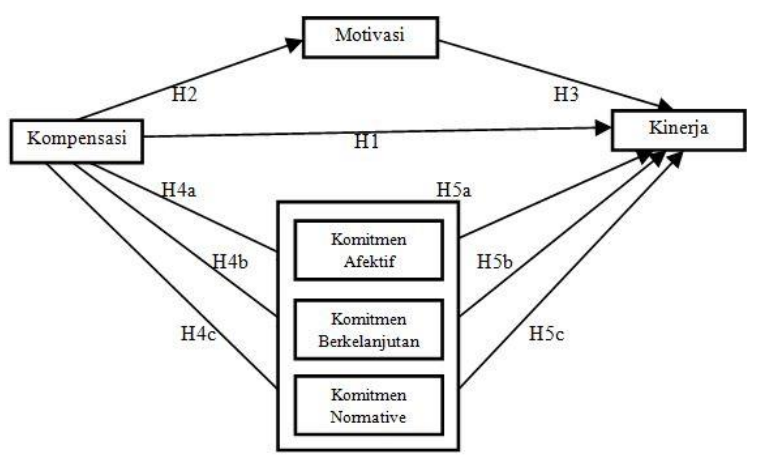

Gambar 1. Model Penelitian

Sumber: hasil proses data

\section{Hipotesis Penelitian}

H1: Kompensasi berpengaruh terhadap kinerja karyawan non manajemen PT.Ewindo.

H2: Kompensasi berpengaruh terhadap motivasi karyawan non manajemen PT.Ewindo.

H3: Motivasi berpengaruh terhadap kinerja karyawan non manajemen PT.Ewindo.

$\mathrm{H} 4 \mathrm{a}$ : Kompensasi berpengaruh terhadap affective commitment karyawan non manajemen PT.Ewindo.

H4b: Kompensasi berpengaruh terhadap continuance commitment karyawan non manajemen PT.Ewindo.

H4c: Kompensasi berpengaruh terhadap normative commitment karyawan non manajemen PT.Ewindo.

H5a: Affective commitment berpengaruh terhadap kinerja karyawan non manajemen PT.Ewindo.

H5b: Continuance commitment berpengaruh terhadap kinerja karyawan non manajemen PT.Ewindo.

H5c: Normative commitment berpengaruh terhadap kinerja karyawan non manajemen PT.Ewindo.

\section{METODE PENELITIAN}

\section{Populasi dan Sampel}

"Populasi merupakan sekelompok yang menjadi perhatian peneliti untuk diteliti" (Sekaran, 2006). Dalam penelitian ini populasi yang dimaksud adalah seluruh karyawan non manajemen PT.Ewindo yaitu karyawan yang terlibat langsung terhadap kegiatan operasional yang berjumlah 200 Orang.

"Sampel merupakan sebagian dari populasi yang terdiri atas sejumlah anggota yang dipilih dari populasi. Dengan kata lain sejumlah, tetapi tidak semua, elemen populasi akan membentuk sampel" (Sekaran, 2006).

Dalam penelitian ini, metode pengambilan sampel dengan menggunakan metode non probability sample yaitu dengan purposive sampling. Purposive sampling adalah pengambilan sampel dilakukan hanya atas dasar pertimbangan penelitinya saja yang menganggap unsur-unsur yang dikehendaki telah ada dalam anggota sampel yang diambil. 
Kriteria dalam purposive sampling ini yaitu:

1. Karyawan non manajemen yang tidak memiliki tugas dalam pengambilan keputusan dan fungsinya lebih kepada operasional perusahaan seperti operator, staf dan yang memiliki tingkatan sama dengan staf.

2. Status karyawan baik itu sebagai pegawai tetap maupun pegawai kontrak.

3. Lama bekerja dari 0 sampai satu tahun, satu sampai dua tahun dan lebih dari dua tahun.

4. Pendidikan minimal tingkat menengah atas (SMA) dan maksimal strata 1 (S1).

Arikunto (2010): "jika subjeknya kurang dari 100 orang sebaiknya diambil semuanya, jika subjeknya besar atau lebih dari 100 orang dapat diambil $10-15 \%$ atau $20-25 \%$ atau lebih. Maka dari itu, penulis mengambil sampel 20\% dari populasi berjumlah 200 orang sehingga sampel dalam penelitian ini adalah 40 orang."

\section{Teknik Pengumpulan Data}

Peneliti menggunanakan kuesioner untuk memperoleh data langsung dari responden, dibuat daftar pertanyaan secara tertulis yang bersifat tertutup. Artinya jawaban alternatif telah disediakan yang mencerminkan skala pendapat tertentu .Skala yang digunakan adalah skala likert dimana menurut Sugiono (2012) "skala Likert digunakan untuk mengukur sikap, pendapat, dan persepsi seseorang atau sekelompok orang tentang fenomena sosial."

\section{Alat Analisis Data}

"Model path analysis (analisis jalur) merupakan perluasan dari analisi regresi linier berganda atau analisis jalur adalah penggunaan analisis regresi untuk menaksir hubungan kausalitas antar variabel (model causal) yang telah ditetapkan sebelumnya berdasarkan teori” (Ghozali, 2007).

Path analysis digunakan untuk menganalisis pola hubungan antar variable dengan tujuan untuk mengetahui pengaruh langsung maupun tidak langsung seperangkat variabel bebas (eksogen) terhadap variabel terikat (endogen).

\section{HASIL PENELITIAN DAN PEMBAHASAN}

\section{Karakteristik Responden}

Tabel 1. Berdasarkan Jenis Kelamin

\begin{tabular}{llcc}
\hline No & Jenis Kelamin & Frekuensi & $(\%)$ \\
\hline 1 & Laki-laki & 30 & 75 \\
2 & Perempuan & 10 & 25 \\
& Total & 40 & 100
\end{tabular}

Sumber: hasil survey 
Tabel 2. Berdasarkan Pendidikan Terakhir

\begin{tabular}{llcc}
\hline No & Pendidikan & Frekuensi & $(\%)$ \\
\hline 1 & SMA Sederajat & 32 & 80 \\
2 & Diploma & 8 & 20 \\
3 & Strata 1 & 0 & 0 \\
& Total & 40 & 100 \\
\hline
\end{tabular}

Sumber: hasil survey

Tabel 3. Berdasarkan

Lama Bek

\begin{tabular}{llcc}
\hline No & Lama Bekerja & Frekuensi & $(\%)$ \\
\hline 1 & $0-1$ Tahun & 3 & 7.5 \\
2 & $1-2$ Tahun & 6 & 15 \\
3 & >2 Tahun & 31 & 77.5 \\
& Total & 40 & 100 \\
\hline
\end{tabular}

Sumber: hasil survey

\section{Rekapitulasi Hasil Tanggapan Responden}

\begin{tabular}{llccrcc}
\hline No & Variabel & $\begin{array}{c}\text { Jenis Butir } \\
\text { Pertanyaan }\end{array}$ & $\begin{array}{c}\text { Skor } \\
\text { Ideal }\end{array}$ & $\begin{array}{c}\text { Skor } \\
\text { Aktual }\end{array}$ & $(\%)$ & Kategori \\
\hline 1 & Kopensasi $(\mathrm{X})$ & 8 & 1600 & 709 & 44.31 & Kurang Baik \\
2 & Motivasi $\left(\mathrm{Z}_{1}\right)$ & 9 & 1800 & 835 & 46.39 & Kurang Baik \\
3 & Affective Commitment $\left(\mathrm{Z}_{22}\right)$ & 8 & 1600 & 755 & 47.19 & Kurang Baik \\
4 & Continuance Commitment $\left(\mathrm{Z}_{21}\right)$ & 8 & 1600 & 1255 & 78.44 & Baik \\
5 & Normative Commitment $\left(\mathrm{Z}_{23}\right)$ & 8 & 1600 & 1164 & 72.75 & Baik \\
6 & Kinerja Karyawan & 9 & 1800 & 898 & 49.89 & Kurang Baik \\
\hline
\end{tabular}

Tabel 4. Rekapitulasi Tanggapan Responden

Sumber: hasil survey

Berdasarkan tabel tersebut bisa diinterpretasikan bahwa karyawan yang berada di PT.Ewindo tetap bertahan karena mereka mempertimbangkan untung atau rugi apabila mereka meninggalkan perusahaan. Mereka khawatir apabila meninggalkan perusahaan, mereka tidak akan mendapatkan pekerjaan yang serupa dengan segala keuntungan yang didapatkan selama menjadi anggota perusahaan saat ini.

Disisi lain, hasil tanggapan untuk pernyataan kuesioner normative commitment yang dikategorikan baik berarti karyawan yang berada pada PT.Ewindo menganggap bahwa sikap loyal kepada perusahaan memang sudah menjadi kewajiban karyawan kepada perusahaannya. 
Tabel 5. Hasil Uji Path Analysis (Parsial)

\begin{tabular}{|c|c|c|c|c|c|c|c|}
\hline No & $\begin{array}{l}\text { Variabel } \\
\text { Independen }\end{array}$ & $\begin{array}{l}\text { Variabel } \\
\text { Dependen }\end{array}$ & $\begin{array}{l}\text { Koefisien } \\
\text { Jalur }\end{array}$ & $\begin{array}{l}\text { Koefisien } \\
\text { Determinasi }\end{array}$ & $\begin{array}{l}\text { t- } \\
\text { Hitung }\end{array}$ & $\begin{array}{l}\text { t- } \\
\text { Tabel }\end{array}$ & Hubungan \\
\hline 1 & Kopensasi (X) & Motivasi $\left(\mathrm{Z}_{1}\right)$ & 0,753 & $56,7 \%$ & 7,047 & 2,024 & Signifikan \\
\hline 2 & Kopensasi (X) & $\begin{array}{l}\text { Affective } \\
\text { Commitment }\left(\mathrm{Z}_{21}\right)\end{array}$ & 0,619 & $38,3 \%$ & 4,853 & 2,024 & Signifikan \\
\hline 3 & Kopensasi (X) & $\begin{array}{l}\text { Continuance } \\
\text { Commitment }\left(\mathrm{Z}_{22}\right)\end{array}$ & 0,597 & $35,6 \%$ & 4,582 & 2,024 & Signifikan \\
\hline 4 & Kopensasi (X) & $\begin{array}{l}\text { Normative } \\
\text { Commitment }\left(\mathrm{Z}_{23}\right)\end{array}$ & 0,600 & $36 \%$ & 4,626 & 2,024 & Signifikan \\
\hline 5 & Motivasi $\left(\mathrm{Z}_{1}\right)$ & Kinerja $(\mathrm{Y})$ & 0,575 & $33,1 \%$ & 4,52 & 2,026 & Signifikan \\
\hline 6 & $\begin{array}{l}\text { Affective } \\
\text { Commitment }\left(\mathrm{Z}_{21}\right)\end{array}$ & Kinerja (Y) & 0,558 & $31,1 \%$ & 5,808 & 2,026 & Signifikan \\
\hline 7 & $\begin{array}{l}\text { Continuance } \\
\text { Commitment }\left(\mathrm{Z}_{22}\right)\end{array}$ & Kinerja (Y) & 0,497 & $24,7 \%$ & 4,909 & 2,026 & Signifikan \\
\hline 8 & $\begin{array}{l}\text { Normative } \\
\text { Commitment }\left(\mathrm{Z}_{23}\right)\end{array}$ & Kinerja (Y) & 0,294 & $8,6 \%$ & 2,427 & 2,026 & Signifikan \\
\hline 9 & Kopensasi (X) & Kinerja (Y) & 0,340 & $11,6 \%$ & 2,67 & 2,026 & Signifikan \\
\hline
\end{tabular}

Sumber: hasil proses data

Dari hasil perhitungan uji path analysis diketahui bahwa antara variabel independen terhadap variabel intervening ternyata kompensasi paling mempengaruhi motivasi karyawan dimana memiliki nilai koefisien jalur yang paling tinggi yaitu sebesar 0,753 dan koefisien determinasi sebesar $56,7 \%$ artinya motivasi dipengaruhi kompensasi sebesar $56,7 \%$ sementara sisanya sebesar $43,3 \%$ dipengaruhi oleh variabel lain.

Sementara itu, motivasi pun menjadi variabel intervening yang paling mempengaruhi dan memidiasi hubungan antara kompensasi dengan kinerja dimana memiliki nilai koefisien jalur sebesar 0,575 dan koefisien determinasi 33,1\%. 
Tabel 6. Hasil Uji Path Analysis Simultan

\begin{tabular}{|c|c|c|c|c|c|c|}
\hline No & $\begin{array}{l}\text { Variabel } \\
\text { Independen }\end{array}$ & $\begin{array}{c}\text { Variabel } \\
\text { Dependen }\end{array}$ & $\begin{array}{c}\text { Koefisien } \\
\text { Determinasi }\end{array}$ & $\begin{array}{c}\text { t- } \\
\text { Hitung }\end{array}$ & $\begin{array}{c}\mathrm{t}- \\
\text { Tabel }\end{array}$ & Hubungan \\
\hline 1 & $\begin{array}{l}\text { Kopensasi }(\mathrm{X}) \\
\text { Motivasi }\left(\mathrm{Z}_{1}\right)\end{array}$ & Kinerja (Y) & $74 \%$ & 52,752 & 3,252 & Signifikan \\
\hline 2 & $\begin{array}{l}\text { Kopensasi }(\mathrm{X}), \\
\text { Affective } \\
\text { Commitment }\left(\mathrm{Z}_{21}\right)\end{array}$ & Kinerja (Y) & $78,9 \%$ & 69,247 & 3,252 & Signifikan \\
\hline 3 & $\begin{array}{l}\text { Kopensasi }(\mathrm{X}) \\
\text { Continuance } \\
\text { Commitment }\left(\mathrm{Z}_{22}\right)\end{array}$ & Kinerja (Y) & $75,6 \%$ & 57,296 & 3,252 & Signifikan \\
\hline 4 & $\begin{array}{l}\text { Kopensasi }(\mathrm{X}) \\
\text { Normative } \\
\text { Commitment }\left(\mathrm{Z}_{23}\right)\end{array}$ & Kinerja (Y) & $65,2 \%$ & 34,708 & 3,252 & Signifikan \\
\hline 5 & $\begin{array}{l}\text { Kopensasi }(\mathrm{X}) \\
\text { Motivasi }\left(\mathrm{Z}_{1}\right) \\
\text { Affective }\end{array}$ & & & & 2,493 & Signifikan \\
\hline & $\begin{array}{l}\text { Commitment }\left(\mathrm{Z}_{21}\right), \\
\text { Continuance } \\
\text { Commitment }\left(\mathrm{Z}_{22}\right) \\
\text { Normative } \\
\text { Commitment }\left(\mathrm{Z}_{23}\right)\end{array}$ & Kinerja (Y) & $88,2 \%$ & 50,959 & & \\
\hline
\end{tabular}

Sumber: hasil proses data

Lalu dari hasil perhitungan path analysis secara simultan ternyata keseluruhan variabel memberikan pengaruh yang besar terhadap kinerja karyawan, bisa dilihat pada tabel diatas kelima variabel memiliki koefisien determinasi sebesar 88,2\% artinya kinerja dipengaruhi oleh kompensasi, motivasi dan komitmen organisasi sebesar 88,2\%, sementara sisanya sebesar 11,8\% dipengaruhi oleh variabel lain.

\section{KESIMPULAN}

Secara parsial baik variabel independaen dan juga variabel intervening berpengaruh signifikan terhadap kinerja karyawan non manajemen. Hal ini bisa dilihat dari hasil uji-t dimana thitung memiliki nilai yang lebih besar daripada $t$ Tabel. Namun, apabila kita lihat dari nilai koefisien jalur dan koefisien determinasi, kompensasi paling mempengaruhi motivasi sementara motivasi memidiasi hubungan antara kompensasi dengan kinerja.

Begitu pula dengan hasil perhitungan secara simultan dimana kelima variabel yaitu kompensasi, motivasi, affective commitment, continuance commitment dan normative commitment memiliki pengaruh yang sangat besar da signifikan terhadap peningkatan kinerja karyawan yaitu sebesar $88,2 \%$ dan sisanya dipengaruhi oleh variabel lain. Penelitian ini memiliki beberapa keterbatasan di antaranya:

1. Sampel penelitian yang digunakan hanya sebesar $20 \%$ dari jumlah populasi, hal ini tentu memiliki pengaruh terhadap tingkat kepercayaan hasil penelitian. Selain itu sampel diambil dari karyawan non manajemen karena penulis menganggap bahwa 
karyawan non manajemen memiliki andil terhadap kinerja perusahaan secara keseluruhan.

2. Uji analisis jalur menggunakan software SPSS V.21, masih terdapat software lain untuk uji analisis jalur seperti SmartPLS dan lain lain.

Penelitian selanjutnya 1) hendaknya menambah jumlah sampel untuk meningkatkan kepercayaan hasil penelitian, 2) dapat dilakukan pada jenis perusahaan selain manufaktur seperti perusahaan dagang ataupun jasa sehingga dapat membuktikan apakah terjadi perbedaan hasil penelitian atau tidak, 3) dapat menggunakan software yang lebih kompleks seperti SmartPLS, dan 4) bagi perusahaan hendaknya lebih memperhatikan terhadap kompensasi karyawan khususnya karyawan non manajemen karena berdasarkan penelitian kompensasi memberikan pengaruh dan kontribusi terhadap motivasi karyawan terkait pencapaian kinerja perusahaan.

\section{DAFTAR PUSTAKA}

Amrullah, A. (2012). Pengaruh Kompensasi Finansial dan Non Finansial terhadap Kinerja Karyawan PT. Bank Rakyat Indonesia (Persero) Tbk. Wilayah Makasar. Makasar: Fakultas Ekonomi dan Bisnis Universitas Hassanudin.

Anthony \& Govindarajan. (2005). Management Control System, Edisi 11 Buku 2, penerjemah: F.X. Kurniawan Tjakrawala, dan Krista. Jakarta: Salemba Empat.

Apriwandi. (2013). Komitmen, Self Efficacy dan Motivasi : Pengaruh Umpan Balik dan Insetif Pada Karyawan Non Manajemen. Proceding dan Seminar Nasional Fakultas Ekonomi UNS 30-31 Mei 2013.

Arikunto, S. (2010). Prosedur Penelitian: Suatu Pendekatan Praktik. (Edisi Revisi). Jakarta: Rineka Cipta.

As'ad, M. (2003). Psikologi Industri: Seri Sumber Daya Manusia, Yogyakarta: Liberty.

Azwar, S. (2009). Reliabilitas dan Validitas (Edisi ke 3). Yogyakarta: Pustaka Pelajar Offset.

Cascio, W.F. (2003). Managing Human Resources. Colorado: Mc Graw-Hill.

Gordon, D.B. (1993). Kerangka Dasar Sistem Informasi Manajemen Bagian I. Jakarta: Pustaka Binaman Presindo.

Drake, A.R., Jeffrey, W. \& Stephen,B.S.. (2007). Empowerment, Motivation, and Performance: Examining the Impact of Feedback and Incentives on Non management Employees. Behavioral Research in Accounting, (19), 71-89.

Eka, I.I.K.L, , Subowo. (2005). Pengaruh Kepemimpinan, Lingkungan Kerja Fisik dan Kompensasi terhadap Kinerja Karyawan di PT.Pertamina (Persero) Daerah Operasi Hulu Jawa Bagian Barat, Cirebon.

Gozhali, I. (2011). Aplikasi Analisis Multivariate Dengan Program IBM SPSS 19 (edisi kelima). Semarang: Universitas Diponegoro.

Greenberg, J.\& Robert, A. B.. (1995). Behavior in Organizations: Understanding and Managing the Human Side of Work. London: Prentice Hall International.

Junaedi. (2002). Balance Scorecard: Pengukuran Kinerja Pada Pemerintah Daerah.No. 2 Kompak, 347-387.

Kondalkar, V.G. (2007). Organizational Behaviour. New Delhi: New Age Internasional (P) Limited, Publishers.

Luthans, F. (1992). Organizational Behavior. Singapore: McGraw Hill

Mahennoko, A.A. (2011). Pengaruh Motivasi Kerja dan Komitmen Organisasi Terhadap Kinerja Pegawai Bidang Keuangan Pada Pemerintah Daerah Kabupaten Demak. Semarang : Universitas Diponegoro.

Marganingsih, A. \& Dwi, M. (2010). Antesenden Komitmen Organisasi dan Motivasi: 
Konsekuensinya Terhadap Kinerja Audit Intern Pemerintah. Jurnal Akuntansi dan Keuangan Indonesia, (7).

McShane, S.L. \& Mary, A.V.G. (2000). Organizational Behavior, McGraw-Hill Companies, Inc., USA.

Moch, N. (2003). Metode Penelitian, Salemba Empat, Jakarta, 63.

Mondy, R.W., Robert, M.N. \& Shane, R.P. (1993). Human Resource Management. $5^{\text {th }}$ Edition. Massachusetts: Allyn and Bacon.

Mulyadi. (2004). Akuntansi Manajemen: Konsep, Manfaat, dan Rekayasa. Edisi Ketiga. Cetakan Ketiga. Jakarta : Salemba Empat.

Mulyadi \& Setiawan, J. (1999). Sistem Perencanaan dan Pengendalian Manajemen: Sistem Pelipatgandaan Kinerja Perusahaan, Edisi 1. Yogyakarta: Aditya Media.

Muyanto, E. (2011). Pengaruh Kompensasi terhadap Kinerja dengan Motivasi Kerja Sebagai Variabel Moderating. Surakarta: Universitas Sebelas Maret.

Murti, W.A. \& Hudiwinarsih, G. (2012). Pengaruh Kompensasi, Motivasi dan Komitmen Organisasional terhadap Kinerja Karyawan Bagian Akuntansi (Studi Kasus pada Perusahaan Manufaktur di Surabaya). The Indonesian Accounting Review, 2 (2), 1-13.

Rama, R.D. (2013) diakses di http://finance.detik.com/read/2013/11/06/144820/2405079/4/pengusaha-klaim-rugiratusan-miliar-akibat-demo-buruh-kemarinpada 12 April 2015.

Djati, S, P., \& M, Khusaini. (2003). Kajian terhadap Kepuasan Kompensasi, Komitmen Organisasi dan Prestasi Kerja. Jurnal Manajemen dan Kewirausahaan, 5 (1).

Sekaran, U. (2006). Research Methods for Business, Edisi 4, Buku 1. Jakarta: Salemba Empat.

Sopiah. (2008). Perilaku Organisasional. Yogyakarta: Andi Offset.

Robbins, S. P., (1996). Perilaku Organisasi, Konsep, Kontroversi dan Aplikasi. Alih Bahasa: Hadyana Pujaatmaka Edisi Keenam. Jakarta: PT.Bhuana Ilmu Populer.

Sudarsono, H. (2008). Analisis Pengaruh Kompensasi terhadap Motivasi dan Kinerja (Studi Kasus Dosen Ekonomi pada Perguruan Tinggi Swasta), Vol.1. Surabaya: Universitas Teknologi Surabaya.

Sudjana. (2003). Teknik Analisis Regresi dan Korelasi. Bandung: Tarsito.

Sugiyono. (2012). Memahami Penelitian Kualitatif. Bandung: ALFABETA.

Sukarno, E. (2002). Sistem Pengendalian Manajemen: Suatu Pendekatan Praktis. Jakarta: PT. Gramedia Pustaka Utama.

Suswati, E. \& Arif. (2013). Komitmen Organisasi Sebagai Salah Satu Penentu Kinerja Pegawai. Malang: Universitas Gajayana Malang. 